https://doi.org/10.18485/iipe_response2covid19.2021.ch1

\title{
CONFRONTING AN UNPRECEDENTED CRISIS WITH LIMITED RESOURCES: THE AFRICAN UNION'S RESPONSE TO COVID-19
}

\begin{abstract}
Ahmed Amal ${ }^{1}$
Abstract: The COVID-19 crisis has caused many negative repercussions for the African Union, either by imposing the health crisis on African countries or by disrupting the efforts of the African Union to accelerate political and economic integration and restore stability on the continent. The African Union exerts continuous efforts to support African countries' fragile healthcare systems, coordinate policies among African countries to avoid harmful competition or contradiction, and mobilize international support to bridge the vast resource gap.

The African continental organization faced a number of obstacles in confronting COVID-19 because of their complete dependence on imported vaccines, African states' inability to launch nationwide vaccination campaigns, disagreements between African states over the vision for institutional and financial reforms of the $\mathrm{AU}$, lack of political commitment, and the politicization of the international "Vaccines War".

On this basis, this paper seeks to review and analyse different types of obstacles that hindered the AU efforts in combating COVID-19 effectively. The paper will be based mainly on data published by the World Health Organization, the African Union and the Africa Centres for Disease Control and Prevention.

Keywords: COVID-19; African Union; Africa Centres for Disease Control and Prevention (Africa CDC); COVID-19 Vaccines Global Access (COVAX); African Integration; Vaccines War.
\end{abstract}

${ }^{1} \mathrm{PhD}$, Lecturer of Political Science, Department of Political Science and Economics, Faculty of Postgraduate African Studies, Cairo University, Egypt; Head of African Studies Unit, Egyptian Center for Strategic Studies (ECSS), Cairo, Egypt, ahmad.amal@cu.edu.eg. 


\section{INTRODUCTION}

The African Union (AU) has gained high aspirations since its establishment to promote integration among African countries and improve the economic and living conditions of its peoples.

The coronavirus pandemic imposed difficult political, financial, and health challenges on the $A U$ when the union was not ready to face a crisis of this magnitude. Exacerbating the crisis further was the attitude of many AU international partners whose COVID-19 support of the African body was not up to par.

This study is meant to investigate the damage the coronavirus pandemic has inflicted on the AU and to review the AU's multiple-pronged response to COVID19 , including health measures, policy coordination, and resource mobilization. The study analyses the major obstacles and challenges the AU has faced in crafting a concerted response to this pandemic.

Finally, it touches upon the reasons that made the AU unprepared for addressing the pandemic, ranging from internal institutional problems and the implications of the complex AU-international partners' network of relations to the decline in health policies at the national and continental levels.

\section{EFFECTS OF THE COVID-19 OUTBREAK ON THE AU}

In early August 2021, 18 months after the first COVID-19 positive case was reported in Africa, the number of confirmed COVID-19 cases in Africa was 6,866,597 with 174,054 deaths (Africa CDC, 2021c). These figures only represent a small portion of the real situation. This could be attributed to several reasons pertaining to the inability of the health sector in African countries to accurately monitor and track COVID-19 cases given the low rate of COVID-19 diagnostic tests conducted (Chitungoet al., 2020, p.2).

Besides the health indicators and what they generally convey, the pandemic has placed immense pressure on the AU and its efforts towards continental integration through promoting self-reliant national approaches and the adoption of precautionary measures. That is in addition to the hesitance over the AU's attempts to build a concerted collective response to the pandemic. Overall, the COVID-19's direct effects on the AU can be detailed as follows:

- Disrupting economic integration between African countries; The AU and African governments' preoccupation with the novel coronavirus has delayed the launch of the African Continental Free Trade Area (AfCFTA) for six months, from June 2020 to January 2021, following a prolonged period of uncertainty after Benedict Okey Oramah, President of the African Export-Import Bank 
(Afreximbank), had postponed the commencement of trading under the AfCFTA (UNDP, 2021, p.71).

- Declining African economic performance; The negative repercussions of the crisis were quickly reflected on Africa's economy. Three months after the first cases of infection in Africa were recorded, the losses of the African continent were estimated at about $\$ 113$ billion, in addition to the $\$ 65$ billion worth of export losses of the top 10 exporting African countries (Gondwe, 2020, p.3). Over time, the economic impact of the pandemic became more severe. The Secretary-General of the AfCFTA announced in June 2021 a 40\% decrease in foreign direct investment in Africa compared to pre-pandemic levels. Given these declining indicators, the AU's plans towards promoting continental economic integration would become the subject of further delays in the future (Soliman, 2021).

- Securitizing national responses; Nationalist individual approaches are still seen by African countries as the most efficient in confronting crises, COVID-19 being no exception. Responding to the pandemic, many African countries have adopted a similar model to China based on greater reliance on coercive tools and invoking security logic in facing "external" dangers. Recognizing the threat of the pandemic as an "external danger", the situation prompted states to protect their citizens through a series of basic security procedures. In this vein, Kenya presented a revealing case where its security approach gave rise to repeated violations during the application of curfews in the capital, Nairobi, and other major cities. This approach, so widely adopted in Africa, would preclude any regional or continental concerted action (Abderrahman, 2020; Ogunnoiki, 2021, pp. 3-4).

- Promoting protective measures like border closure; The World Bank data indicates that African countries have adopted multiple forms of restricting crossborder flows at an early stage. By the end of March 2020, 32 African countries had put in place restrictions on flights, 31 countries announced the full closure of their land borders, and 10 countries introduced restrictions on the flow of incoming and outgoing goods (Brenton \& Chemutai, 2020, p. 2). According to the COVID-19 Travel Regulations Map of the International Air Transport Association (IATA) published in July 2021, all African countries imposed partial restrictions on entry, except Libya and Malawi, where entry was totally restricted (IATA, 2021). Additionally, several African host countries sent immigrants back to their homes to lessen the burden of combating the spread of the pandemic. Between March and June 2020, countries of the Southern African Development Community (SADC) saw the return of 63,000 immigrants to their home countries (SSHAP, 2020, p. 3). 


\section{THE AU'S RESPONSE TO COVID-19}

The AU responded quickly to the coronavirus on two levels. Directly, the AU provided healthcare support to member states to address the crisis, including the provision of the anti-virus vaccines. Indirectly, the AU played an active role in coordinating COVID-19 policies of its member states to reduce discrepancies that might have limited the effectiveness of the African response and addressing international donors to mobilize large resources with the aim of supporting African countries in dealing with this emergency crisis.

\section{Supporting the African Healthcare System}

Traditionally, the AU does not have great healthcare capabilities. Its prominent organizational development in this respect came only three years before the coronavirus emerged, when the role of the Africa Centers for Disease Control and Prevention (Africa CDC) was activated only in January 2017. With the outbreak of the coronavirus, the Africa CDC took more rapid steps to confront the pandemic, including activating the Emergency Operations Center in February 2020 and establishing the continent-wide African Task Force for Novel Coronavirus (AFTCOR) (Fagbayibo, 2021, p. 6).

Furthermore, the African Union Commission (AUC) and the Africa CDC launched a new initiative, "Partnership to Accelerate COVID-19 Testing: Trace, Test, and Track", aimed at increasing continental testing of COVID-19 with a focus on countries with limited capacities and fragile healthcare institutional structures to ensure at least 10 million Africans are tested for the coronavirus. Moreover, with the support of the World Health Organization (WHO), the Africa CDC's role in training has been revitalized when it provided training to representatives of the AU member states on how to conduct COVID-19 laboratory tests. In July 2020, the Africa CDC launched a new program called "Consortium for COVID-19 Vaccine Clinical Trial" (CONCVACT) geared towards eliminating all obstacles that may stand in the way of conducting clinical trials for vaccines in African countries (Fagbayibo, 2021, p. 7).

With the start of the global COVID-19 vaccination campaign, the AU was left in the lurch, given its complete dependence on imported vaccines. The AU partnered with the Africa CDC to develop a continental strategy for the development and provision of the COVID-19 vaccines called the "Vaccine Development and Access Strategy", which was officially adopted in August 2020, aiming at ensuring Africa's equitable access to the COVID-19 vaccines (Africa CDC, 2020b).

Moreover, the African Vaccine Acquisition Task Team (AVATT) was established to act as the executive body concerned with supporting Africa's vaccine strategy. 
The main task of AVATT is to coordinate with the COVID-19 Vaccines Global Access (COVAX) initiative, launched by the WHO in collaboration with a number of international partners, in order to provide the COVID-19 vaccines for African countries (Fagbayibo, 2021, p. 10).

\section{Coordination of Policies Among African Countries}

Since the outbreak of the virus, the AU has tried to fulfil its expected role in coordinating the efforts of African governments in facing the spread of COVID-19. At their meeting at the headquarters of the AU in Addis Ababa on 22 February 2020, African Ministers of Health endorsed the "Africa Joint Continental Strategy for COVID-19 Outbreak", which was later approved by the Assembly of Heads of State and Government of the AU on 26 March. The strategy comprises two tracks to respond to the crisis: 1 ) taking measures to prevent the spread of the pandemic and 2) working to contain the economic damage and dispel the social disorder caused by the spread of the virus (Africa CDC, 2020a, p. 3).

On 3 April 2020, African leaders held a teleconference meeting, attended by heads of nine African countries, namely South Africa, Egypt, the Democratic Republic of the Congo, Senegal, Kenya, Mali, Ethiopia, Rwanda, and Zimbabwe, with the participation of the Chairperson of the AUC, President of the WHO, Head of the Africa CDC, and the French President Emmanuel Macron in order to foster a continental response to the pandemic (AU, 2020b).

The summit endorsed a number of important resolutions, including the establishment of the African Union COVID-19 Response Fund to develop secure transportation routes between African countries to facilitate the transport of goods and medical supplies. The resolutions also included boosting the AU's management capacity to organize a coordinated continental response. The AU Commission announced the appointment of three special envoys to mobilize international economic support for Africa's efforts to face the crisis (AU, 2020a).

\section{Mobilizing Resources and International Support}

The Bureau of the African Union Heads of State and Government established the African Coronavirus Fund to provide urgent assistance for the countries on the continent. These efforts included purchasing and distributing essential medical equipment and supplies and containing the negative social and economic repercussions of the pandemic. The African Union Bureau approved initial funding for the Fund in the amount of $\$ 12.5$ (AU, 2020b). 
The African Development Bank announced the launch of a $\$ 10$ billion rapid response initiative to help member countries take health protection measures to curb the economic and social repercussions of the pandemic (ADB, 2020).

The AU formed the Taskforce on COVID-19 Impact on Food Security and Nutrition in Africa. The task force includes the AUC, the African Union Development Agency, the NEPAD, the FAO, the European Commission, the World Bank, and the African Development Bank to implement the recommendations approved by the African agriculture ministers on addressing food security and nutrition challenges caused by the pandemic and the measures taken to address it (FAO, 2020).

\section{SUBSTANTIAL OBSTACLES THE AU IS FACING IN RESPONDING TO COVID-19}

By June 2021 , approximately $11 \%$ of people worldwide will have received the first dose of the COVID-19 vaccine. In Africa, this percentage is less than $2 \%$. Fewer than 0.6 per cent of Africans received two vaccine doses, according to Our World in Data (OWID). Therefore, the vaccination rate against COVID-19 in Africa is considered the slowest in the world. Despite the fact that many African countries announced the launch of their vaccination programs in the second half of 2020 when 49 African states were able to vaccinate their citizens with approximately 22 million doses, Seychelles was the only state in Sub-Saharan Africa that had vaccinated 60 per cent of its citizens by May 2021, while the vast majority of African states have a vaccination rate of less than 5 per cent (OWID, 2021).

Many substantial issues have played a key role in slowing down the vaccination process in Africa, which are directly related to healthcare sector problems in African countries and the lack of adequate capabilities of the AU to support African healthcare systems. This category of obstacles includes:

\section{AU Limited Healthcare Institutional and Logistical Capabilities}

In April 2001, AU heads of state met in the Nigerian capital, Abuja, and pledged to dedicate no less than 15 per cent of the annual budget to improve the health sector. At the same time, the Abuja Declaration encourages donor countries to devote 0.7 per cent of their GDP to help nurture developing countries. The highlevel African interest came to reveal the early interest of the AU in the health sector, which has been making more prominent appearances at the level of meetings and documents issued by the $\mathrm{AU}$ without corresponding progress in policy implementation (WHO, 2011, pp. 1-3). 
The most significant achievement of the AU has been the establishment of the Africa CDC. It was established to support the public health initiatives of member states and to strengthen the capacity of public health institutions to detect, prevent, control, and respond quickly and effectively to diseases. According to the founding document, the Africa CDC supports member states in providing coordinated and integrated solutions to deficiencies in public health infrastructure, human resource capacity, disease surveillance, laboratory diagnosis, and response to health emergencies and disasters (Nkengasong et al., 2017, p. 16).

The Africa CDC was founded in January 2016 as per a decision of the 26th Ordinary Summit of African Heads of State and Governments, officially launched in January 2017. The coronavirus is the first real crisis with which the Africa CDC deals with owing to its relatively recent founding history, with only one previous prominent role in the Ebola outbreak in Kivu, northeast of the Democratic Republic of Congo, which lasted between August 2018 and June 2020 (Africa CDC, 2019). That indicates that the Africa CDC needs more time and experience to be able to deal with health crises on a continental scale.

\section{Dependence on Imported Vaccines Because of Limited Inoculation Alternatives}

Forty African countries dependent on the COVAX initiative were affected by the decision not to send vaccines to Africa due to the high incidence of disease in India. African countries were able to receive their first vaccine shares by the beginning of 2021 through the coordination of the AU with the Global COVAX mechanism (COVAX, 2021, p. 1).

Despite the promising start of vaccine supply operations to African countries, this progression was hit when India announced in March that it had stopped exporting vaccine doses produced at the Serum Institute of India. This institute produces the AstraZeneca vaccine, which is one of the most widely used vaccines in Africa. This decision had an extended negative impact as the WHO announced that the COVAX vaccine supply mechanism would suffer from a shortfall of up to 190 million doses in June, which resulted in a significant disruption of vaccination programs in African countries (Bhalla \& Yi, 2021).

What worsens the problem of the inability to export vaccines to African countries is the difficulty of finding available alternatives, namely, the manufacture of vaccines in African countries or financing their purchase away from the COVAX initiative (Abiodun et al., 2021, p. 6).

Concerning the first alternative, the majority of the African countries do not have an infrastructure for pharmaceutical industries to produce vaccines in large 
quantities that meet the shortfall at a continental or regional level. Egypt was the first to sign agreements to manufacture the Chinese Sinovac and the Russian Sputnik vaccines (Leila, 2021). In addition, the WHO announced the intention of a group of international companies to establish a MRNA vaccine manufacturing centre in South Africa without disclosing the release date (WHO, 2021b).

As for the second alternative of financing vaccines from national budgets or bilateral international grants, the majority of African countries do not have the financial capacity to purchase vaccines in sufficient numbers. In addition, many large donor countries also consider that they may experience a new COVID-19 wave, which makes them more cautious in giving the vaccines they own or pledging to supply significant quantities of vaccines in the future (CABRI, 2021, pp.6-8).

\section{Inability to Launch Nationwide Vaccination Campaigns}

Because of African states' weak logistical capacity, the WHO called on African countries to provide the first dose of the vaccine to the largest number of citizens, as it has a short expiry date. This call came after vaccinations in some African countries had been stalled; only eight African countries were able to use all doses of vaccines received via the COVAX initiative. Moreover, nine countries used less than a quarter of their received doses, and 15 countries used only half of their received doses (WHO, 2021c).

Field data show that Benin, Cameroon, Central African Republic, the Democratic Republic of the Congo, Guinea, Comoros, and South Sudan have already used less than 10 per cent of the total vaccines received. To date, the WHO data indicates that only 10 African countries have been able to use all the doses obtained from the COVAX initiative, namely Botswana, Swaziland (eSwatini), Lesotho, and Namibia in southern Africa, Tunisia, Morocco, and Libya in the north of the continent, Côte $d^{\prime}$ Ivoire and Togo in the west of the continent, as well as Rwanda (Eisele, 2021).

Additionally, insecurity had a severe impact on hindering inclusive vaccination campaigns in Africa. For example, many international organization reports have referred to the collapse of the health system in the Tigray region in northern Ethiopia since a violent conflict broke out in November 2020 between the federal and regional governments (OCHA, 2021, p.89). This is in addition to areas of near-chronic conflicts, such as conflicts in the Eastern Congo, central Somalia, northern Mali, and north-eastern Nigeria, which are under ineffective control of their governments and where no successful vaccination campaign can be launched (Desmidt and Neat, 2021, pp. 4-5). 


\section{Declining Health Care Expenditure in African Countries}

Since the 1980s, when African countries adopted structural adjustment programs one after the other, public spending priorities have witnessed profound and radical changes, which have imposed significant constraints on any increase in public spending on social services, including health services (Lowenson, 1993, p. 723).

According to the WHO statistics on sub-Saharan Africa's spending on the health sector between 2000 and 2018, several important trends can be seen, most notably the fact that in 2018, the ratio of health sector spending to GDP in sub-Saharan Africa stood at only 5 per cent, at a time when the world average recorded 9.8 per cent. That represents a decrease from earlier periods in Sub-Saharan Africa, when spending on the health sector as a percentage of GDP exceeded 5.5 per cent in 2003 and 2004 before beginning to decline (WHO, 2021a).

Given the figures for sub-Saharan Africa in health spending, two major problems can be detected. The first relates to the very low ratio of health sector spending to the GDP in some cases, with only three per cent of GDP or less in Angola, Benin, the Republic of the Congo, Gabon, Cameroon, the Democratic Republic of the Congo, Equatorial Guinea, Ethiopia, Guatemala, Ghana, Guinea, Mali and Nigeria, and Senegal. The second problem concerns the sharp decline in health sector spending in the last 20 years, experienced by states, such as Cameroon, Chad, Comoros, Eritrea, Ethiopia, Guatemala, southern Sudan, Uganda, and Zimbabwe (WHO, 2021a).

This deteriorating trend provides clear evidence that the greater deficit in the capacity of African governments to respond to the pandemic is essentially related to the financing issue, which is beyond the capacity of the continental organization given the complex financing problems experienced by the $\mathrm{AU}$ in recent years, which has prevented it from mobilizing and redirecting funding surplus to support the health sector in the neediest African states (WHO, 2013, p.10).

\section{CONTEXTUAL OBSTACLES OF THE AU IN RESPONDING TO COVID-19}

The reactions of the $A U$ to the outbreak of the coronavirus reflected a great deal of responsiveness and sensitivity to continental problems. The high-level meetings and successive official documents issued by various AU bodies actualized the union's genuine interest in assisting African countries. However, the continental and international political context posed serious challenges to the AU's response through a number of obstacles, namely: 


\section{Disagreements over the Vision for Institutional and Financial Reforms of the $\mathrm{AU}$}

Less than two decades after the establishment of the African Union, the needs of the continental organization have begun to develop institutionally as a matter of urgency, as has been revealed by many practices on the ground. Based on that, the AU held the Kigali Summit in July 2016, which was devoted to addressing the issue of institutional development of the $\mathrm{AU}$ by focusing on developing the funding system for its activities (Turianskyi and Gruzd, 2019, pp. 13-18).

As a result of the $A U^{\prime}$ 's increasing reliance on grants from non-African states and institutes to finance its activities, the issue of reorganizing the member states' funding of the activities, which includes the erasure of the reliance on African sources, was suggested as the main goal. According to the scheme announced at the Kigali meeting, the plan was supposed to be implemented in 2016, 2017, and 2018, but this did not materialize (Apiko and Aggad, 2018, pp. 4-5).

Reforming the AU's financing system has accidentally brought to the surface deep internal disagreement between the most contributing and the neediest AU member states. As a result of the slow progress in funding reform, the neediest African states now accuse the leading main African contributor states of obstructing institutional and financial reform schemes of the continental organization.

In contrast, the response from the other side is clearly based on the principle of equitable distribution of the AU burden, at a time when a few countries, namely Algeria, Egypt, Morocco, Nigeria, and South Africa, have borne the bulk of it, and have shown their criticism of the new funding system, which has increased the annual contribution of Egypt, Algeria, Nigeria, and South Africa from about \$16 million in 2015 to more than $\$ 36$ million in the following three years, according to the reports of the AU's financial needs. This is in addition to some proposals for reform of the union's financing system that have sought to link the contribution of each African state to its public revenues, which a significant number of member states see as exceeding their financial sovereignty (Engel, 2018, p.30).

In 2018, an AU report monitoring the commitment of the member states to the decisions of the Kigali Summit on AU financial and institutional reform found six countries committed, eight states taking preliminary steps in this direction, while 30 states refrained from taking any steps that would reflect their commitment to the decisions of the Kigali Summit (African Union, 2018, pp. 4-8). In conclusion, obstacles to the reform of the financing system of the AU continue to be one of the main sources of reducing the readiness of the continental organization to deal with a crisis as big as the outbreak of the coronavirus. 


\section{Lack of Political Commitment}

In terms of principles and measures, the behaviours of many African governments do not meet the AU vision for addressing COVID-19. Many African leaders have embraced populist approaches in dealing with COVID-19 and have disregarded providing the vaccines or supporting international efforts in vaccinating their citizens (Patterson and Balogun, 2021, p. 13). Several African leaders tried to use cultural challenges to enhance their popularity, even at the expense of adopting effective policies to confront the pandemic. In many African countries, prevailing culture has created a hostile or unwelcoming environment for vaccination campaigns due to the denial and questioning of the pandemic or reliance on traditional treatments, under the rumour that vaccines imported from abroad have extremely serious side effects, a rumour that is widely familiar in African societies (ACSS, 2021). Those cultural challenges stand before the vaccination efforts. In Malawi, over 17,000 doses of vaccines were destroyed in June 2021 due to media campaigns that strongly promoted the serious side effects of the AstraZeneca vaccine (Eisele, 2021).

Lack of political commitment has been manifested internationally. Although the World Bank estimates that African countries need funding of $\$ 12$ billion to curb the spread of COVID-19, the African continent has only received a COVAX initiative pledge to provide 30 per cent of Africa's vaccine needs, while a funding gap of more than 70 per cent of the required funding remains (WB, 2020).

This complex situation led Strive Masiyiwa, Special Envoy of the African Union, to help coordinate efforts to procure the COVID-19 vaccines. He held a press conference at the end of June 2021, declaring that the European states and the COVAX mechanism had failed the African continent and did not fulfil their commitments to provide sufficient vaccines to African countries. In addition, he noted that the EU factories did not provide any doses for African countries, and the COVAX initiative had helped withhold information highlighting the failure of major donors to fulfil their commitments to the African continent. Furthermore, the African Envoy noted that COVAX had already pledged 700 million doses to African countries by December 2021. But the number of vaccines delivered to the continent reached only 50 million doses from the initiative and 15 million from multiple international donors (Cullinan, 2021).

\section{The politicization of the "Vaccines War"}

Africa has traditionally experienced fierce competition between many external powers, which have been able to shape many political, military, and economic 
situations on the continent. At a time when the intense presence of players on African soil was expected to help the African continent overcome the pandemic, the crisis has become a new arena for competition between foreign powers to gain more influence and control over African states (Devermont and Olander, 2020).

This unusual competition became public at the end of June 2021, when Josep Burrell, the European Union's High Representative for Foreign Policy, hinted that China was more active than the European Union in supplying the anti-coronavirus vaccines to Africa in order to increase its geopolitical influence on the continent, recalling a previous European pledge to grant the African continent 200 million doses of the vaccine, while at the same time only 10 million doses were granted (Von Der Burchard, 2021; Deutsch and Furlong, 2021).

It is inappropriate to approach the European-Chinese competition to supply vaccines to the African continent with a narrow view of the scope of impact or timeframe since the urgent need for vaccines will cost African states a lot in the future because it is expected not to be confined only to the health sector.

\section{CONCLUSION}

The COVID-19 pandemic is an unprecedented crisis for the AU, according to indicators of wide geographical range, rapid escalation, and severity. Many African countries, particularly those with limited healthcare capacities, were counting on the $A U$ to handle a slew of urgent tasks, the first of which was to provide the necessary preventive supplies and logistical preparations to improve their hospitals' ability to receive patients. The second task that the AU was expected to do was to ensure that the African continent received a fair portion of the anti-coronavirus vaccine, or at very least, to improve African states' negotiating position with global efforts and pharmaceutical corporations. Lastly, the AU was expected to play a more active role in coordinating national policies to combat and prevent the spread of the coronavirus, so that many African sectors could have avoided unnecessary suffering as a result of the conflict between policies designed nationally, primarily in border areas of African states and economic sectors that rely on cross-border trade, which have lost their livelihood immediately and directly as a result of border closure policies.

On this basis, a clear conclusion can be drawn: While the AU has shown a strong interest and responsibility in assisting in the early detection and treatment of the coronavirus, several constraints inherited from previous years have limited the AU's ability to provide a successful and effective response to the virus.

The African continental organization faced several substantial obstacles in confronting COVID-19 because of its limited institutional and logistical capabilities 
in supporting healthcare systems and as a result of its complete dependence on imported vaccines. The AU was also obliged to tackle African states' inability to launch nationwide vaccination campaigns, which is one of various repercussions of declining healthcare expenditure over the past two decades. Contextual obstacles have complicated the AU's mission in mitigating the pandemic negative effects. Disagreements between African states over the vision for institutional and financial reforms of the $A U$ have restricted its ability to increase self-reliance in financing the implementation of its anti-COVID-19 strategy. Lack of political commitment continentally and the politicization of the "Vaccines War" internationally were crucial causes of the weakening of the AU's response to the pandemic.

Although the AU has attempted to respond appropriately to the pandemic with its available institutional, financial, and political capabilities, there are still many ways that can be adopted to improve the future returns from this response, especially given the lack of any expectation of a rapid end to the pandemic. It is important that the $\mathrm{AU}$, in cooperation with sub-regional organizations, play an active role in coordinating national policies among the $A U$ member states to avoid the negative effects of the disruption or contradiction of such policies in vital areas such as the closure of international borders. It remains essential for the AU to promote a unified African stance that exerts maximum pressure on the international community at various relevant forums to ensure obtaining an equitable share of vaccines for all African countries. In the medium and long term, there is an urgent need for the AU to play a more active role in the formulation of an integrated African pharmaceutical industry policy that will strengthen African infrastructure in this area and make the continent more prepared to face similar problems when they are repeated in the future.

Overall, the coronavirus pandemic has put great pressure on the $A U$, testing the ability of the continental organization to respond to specific health problems and yielding numerous lessons learned that will have multiple positive implications for the AU's future development.

\section{REFERENCES}

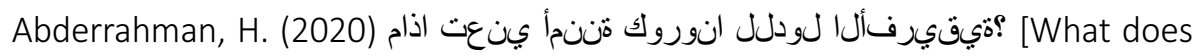
securitization of Covid-19 mean to African States?]. Future for Advanced Research \& Studies, retrieved from https://futureuae.com/ar/Mainpage/ Item/5510. Accessed 2 August 2021.

Abiodun et al. (2021). Vaccine Manufacturing in Africa: What It Takes and Why It Matters. Tony Blair Institute for Global Change, retrieved from https://institute. 
global/sites/default/files/articles/Vaccine-Manufacturing-in-Africa-What-ItTakes-and-Why-lt-Matters.pdf. Accessed 2 August 2021.

ACSS. (2021, May 21). Dispelling COVID Vaccine Myths in Africa. Africa Center for Strategic Studies, retrieved from https://africacenter.org/spotlight/dispellingcovid-vaccine-myths-in-africa/. Accessed 2 August 2021.

ADB. (2020, June 13). African Development Bank COVID-19 response: moving from commitment to action. African Development Bank Group, retrieved from https://www.afdb.org/en/news-and-events/african-development-bank-covid19-response-moving-commitment-action-36188. Accessed 5 August 2021.

Africa CDC. (2020a). Adapted Africa JointContinental Strategy forCOVID-19 Pandemic. Africa Centres for Disease Control and Prevention, retrieved from https://africacdc.org/download/africa-joint-continental-strategy-for-covid-19outbreak/. Accessed 5 August 2021.

Africa CDC. (2020b). COVID-19 Vaccine Development and Access Strategy.Africa Centres for Disease Control and Prevention, retrieved from https://africacdc.org /download/covid-19-vaccine-development-and-access-strategy/. Accessed 2 August 2021.

Africa CDC. (2019, August 27). Ebola Virus Disease Outbreak in the Democratic Republic of Congo. Epidemiological Week 34. Africa Centres for Disease Control and Prevention, retrieved from https://africacdc.org/wp-content/uploads/ 2019/10/Ebola-Virus-Disease-Outbreak-190827.pdf. Accessed 2 August 2021.

Africa CDC. (2021c, August 2). Coronavirus Disease 2019 (COVID-19): Latest updates on the COVID-19 crisis from Africa CDC, Africa Centres for Disease Control and Prevention, retrieved from https://africacdc.org/covid-19/. Accessed 5 August 2021.

Apiko, P. and Aggad, F. (2018). Analysis of the implementation of the African Union's $0.2 \%$ levy: progress and challenges (Briefing Note No. 98). European Centre for Development Policy Management, retrieved from https://ecdpm.org/wpcontent/uploads/BN98-Apiko-Aggad-November-2017.pdf. Accessed 10 August 2021.

AU. (2020a, April 12). Decision on the Establishment of The African Union Covid-19 Response Frnd. African Union, retrieved from https://au.int/en/decisions/ decision-establishment-african-union-covid-19-response-fund. Accessed 2 August 2021.

AU. (2020b, April 3). Communiqué of the African Union (AU) Bureau of Heads of State and Government Teleconference Meeting. African Union, retrieved from https://au.int/en/pressreleases/20200403/communique-african-union-aubureau-heads-state-and-government-teleconference. Accessed 5 August 2021. 
AU. (2018, December 28). Financing The Union: Towards the financial autonomy of the African Union. African Union, retrieved from https://au.int/sites/default/ files/newsevents/workingdocuments/35691-wd-financing_of_the_union_ report___december_-_english.pdf. Accessed 15 August 2021.

Bhalla, N. and Yi, B. L. (2021, May 20). World Set to Be 190 Million Vaccine Doses Short as Mega-Producer India Halts Exports: UNICEF. Global Citizen, retrieved from https://www.globalcitizen.org/en/content/india-halts-export-covaxvaccine-poorest-countries/. Accessed 1 August 2021.

Brenton P., \& Chemutai, V. (2020). Trade and COVID-19 Guidance Note: Trade Responses to The Covid-19 Crisis In Africa. World Bank Group, retrieved from https://documents1.worldbank.org/curated/en/370831586274809825/pdf/Tra de-Responses-to-the-COVID-19-Crisis-in-Africa.pdf. Accessed 2 August 2021.

CABRI. (2021). COVID-19 vaccine financing, procurement and distribution in African ministries of finance and health. CABRI Working Paper. Collaborative Africa Budget Reform Initiative (CABRI), retrieved from https://www.cabri-sbo. org/uploads/files/Documents/CABRI-Working-Paper-COVID-19-vaccinefinancing-procurement-and-distribution-in-African-ministries-of-finance-andhealth.pdf. Accessed 5 August 2021.

Chitungo, I. et al. (2020). COVID-19: Unpacking the low number of cases in Africa. Public Health in Practice, 1(1). doi: 10.1016/j.puhip.2020.100038

COVAX. (2021, February 3). The COVAX Facility: Interim Distribution Forecast. COVID19 Vaccines Global Access, retrieved from https://www.gavi.org/sites/ default/files/covid/covax/COVAX-Interim-Distribution-Forecast.pdf. Accessed 5 August 2021.

Cullinan, K. (2021, July 1). African Union Special Envoy Slams COVAX as COVID Deaths Spike on the Continent, Urges Donors to 'Pay up' on Vaccine Pledges. Health Policy Watch, retrieved from https://healthpolicy-watch.news/africanunion-special-envoy-slams-covax-as-covid-deaths-spike-on-the-continenturges-donors-to-pay-up-on-vaccine-pledges/. Accessed 5 August 2021.

Desmidt, S. and Neat, A. (2021). COVID-19 vaccines: the challenges of protecting Africa's fragile regions (Briefing Note No. 129). European Centre for Development Policy Management, retrieved from https://ecdpm.org/wpcontent/uploads/COVID-19-Vaccines-Challenges-Protecting-Africa-FragileRegions-ECDPM-Briefing-Note-129-March-2021.pdf. Accessed 2 August 2021.

Deutsch, J. and Furlong, A. (2021, August 2). EU falls behind China, US on vaccine donations: Document. Politico, retrieved from https://www.politico.eu /article/europe-coronavirus-vaccine-donations-china-united-states/. Accessed 15 August 2021. 
Devermont, J. and Olander, E. (2020, March 18). COVID-19 Is an African Political Crisis as Much as a Health and Economic Emergency. Center for Strategic International Studies (CSIS), retrieved from https://www.csis.org/analysis/covid19-african-political-crisis-much-health-and-economic-emergency. Accessed 10 August 2021.

Eisele, I. (2021, June 4). Coronavirus: Africa in dire need of vaccines. DW, retrieved from https://www.dw.com/en/coronavirus-africa-in-dire-need-of-vaccines/a57778694. Accessed 7 August 2021.

Engel, U. (2018). The Road to Kigali: The AU Finances between Dependence and Increasing Ownership. In Mbabazi, P. (ed.) A Wind of Change? The Institutional Reform of The African Union and Africa's Security Provision. (pp. 25-37). Institute for Peace and Security Studies, Addis Ababa University.

Fagbayibo, B. (In Press). Crisis as Opportunity: Exploring the African Union's Response to Covid-19 and the Implication for its Aspirational Supranational Powers. Journal of African Law.doi:10.13140/RG.2.2.20574.77121

FAO. (2020, May 5). Task Force Focusing on Impacts of COVID-19 on Africa's Food Security Begins Work. Food and Agriculture Organization of the United States. retrieved from http://www.fao.org/e-agriculture/news/task-force-focusingimpacts-covid-19-africa\%E2\%80\%99s-food-security-begins-work. Accessed 5 August 2021.

Gondwe, G. (2020). Assessing the Impact of COVID-19 on Africa's Economic Development. United Nations Conference on Trade and Development. retrieved from https://unctad.org/system/files/official-document/aldcmisc2020d3_en. pdf. Accessed 7 August 2021.

IATA. (2020). COVID-19 Travel Regulations Map (powered by Timatic). International Air Transport Association. retrieved from https://www.iatatravelcentre.com/ international-travel-document-news/1580226297.htm. Accessed 7 August 2021.

Leila, R. (2021, June 24). Egypt's COVID-19 vaccine self-sufficiency, a new step towards national immunity. Ahram Online. Retrieved from https://english. ahram.org.eg/NewsContent/50/1201/414844/AlAhram-Weekly/Egypt/EgyptsCOVID-vaccine-selfsufficiency,-a-new-step-t.aspx. Accessed 9 August 2021.

Loewenson, R. (1993). Structural Adjustment and Health Policy in Africa. International Journal of Health Service. 23(4). 717-730. doi: 10.2190/WBQL-B4JPK1PP-J7Y3

Nkengasong, J. et al. (2017). Establishing the Africa Centres for Disease Control and Prevention: the upside of a crisis. Lancet Global Health. 5(3). 246-247. doi: 10.1016/S2214-109X(17)30025-6 
OCHA. (2021, February 28). Ethiopia- Tigray Region Humanitarian Update. OCHA Situation Report. United Nations Office for the Coordination of Humanitarian Affairs. Retrieved from https://reliefweb.int/sites/reliefweb.int/files/resources/ Situation\%20Report\%20-\%20Ethiopia\%20-\%20Tigray\%20Region\%20 Humanitarian\%20Update\%20-\%2028\%20Feb\%202021.pdf. Accessed 10 August 2021.

Ogunnoiki A.O. (2021). The Securitisation of Covid-19 in a Globalised World. Renaissance University Journal of Management and Social Science (RUJMASS). 7(1), pp. 1-6. https://rujmass.com/Journals/2021/001.pdf

Our World in Data. (2021).Coronavirus (COVID-19) Vaccinations. retrieved from https://ourworldindata.org/covid-vaccinations. Accessed 5 August 2021.

Patterson, A.S. and Balogun, E. (2021). African Responses to COVID-19: The Reckoning of Agency? African Studies Review. 64 (1). 1-24.doi: 10.1017/asr.2020.122

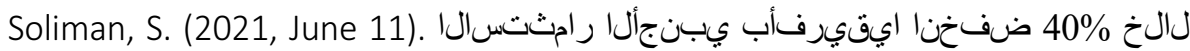
[تحئاجل from https://www.elwatannews.com/news/details/5527499.Accessed 2 August 2021.

SSHAP. (2020). Key Considerations: Covid-19 RCCE Strategies for Cross Border Movement In East Ern And Southern Africa. Social Science in Humanitarian Action Platform, retrieved from https://reliefweb.int/sites/reliefweb.int/files/ resources/SSHAP_ESAR_Cross_Border_RCCE\%20.pdf. Accessed 2 August 2021.

The World Bank. (2020, March 3). World Bank Group Announces Up to \$12 Billion Immediate Support for COVID-19 Country Response, retrieved from https://www.worldbank.org/en/news/press-release/2020/03/03/world-bankgroup-announces-up-to-12-billion-immediate-support-for-covid-19-countryresponse. Accessed 2 August 2021.

Turianskyi, Y. and Gruzd, S. (2019). The 'Kagame Reforms' of the AU: Will they stick? (Occasional Paper 299). South African Institute of International Affairs (SAllA), retrieved from https://saiia.org.za/research/the-kagame-reforms-of-the-au-willthey-stick/. Accessed 5 August 2021.

UNDP. (2021). Analysing long-term socio-economic impacts of COVID-19 across diverse African contexts. UNDP Regional Bureau for Africa, retrieved from https://www.undp.org/content/dam/rba/docs/Reports/Report\%20-\%20Socioeconomic\%20impacts\%20of\%20COVID-19\%20-\%20March\%202021.pdf. Accessed 5 August 2021. 
Von Der Burchard, H. (2021, July 30). Borrell: EU's 'insufficient' vaccine donations open door for China. Politico, retrieved from https://www.politico.eu/article /josep-borrell-eu-vaccine-donations-insufficient/. Accessed 2 August 2021.

WHO. (2021a). Global Health Expenditure Database. World Health Organization, retrieved from https://apps.who.int/nha/database. Accessed 2 August 2021.

WHO. (2021b, July 30). New consortium working to boost vaccine production in South Africa. World Health Organization, retrieved from https://www.who. int/news/item/30-07-2021-new-consortium-working-to-boost-vaccineproduction-in-south-africa. Accessed 5 August 2021.

WHO. (2021c, May 14). Risks and challenges in Africa's COVID-19 vaccine rollout. World Health Organization, retrieved from https://www.afro.who.int/news/ risks-and-challenges-africas-covid-19-vaccine-rollout. Accessed 2 August 2021.

WHO. (2013). State of Health financing in The African Region. World Health Organization, Regional Office for Africa, retrieved from https://www.afro.who. int/sites/default/files/2017-06/state-of-health-financing-afro.pdf. Accessed 2 August 2021.

WHO. (2011). The Abuja Declaration: Ten Years On. World Health Organization, retrieved from https://www.who.int/healthsystems/publications/Abuja10.pdf. Accessed 10 August 2021. 